\title{
INOVASI KEGIATAN MENCEGAH IBU HAMIL KEK (BULAT BRONIS) DI KAMPUNG MADIUN KEL.RAJABASA RAYA KEC.RAJABASA BANDAR LAMPUNG TAHUN 2021
}

\author{
Devi Kurniasari ${ }^{1}$, Rosmiyati ${ }^{2}$ \\ ${ }^{1,2}$ Program Studi Kebidanan Universitas Malahayati \\ Email: devikurniasari82@gmail.com
}

\begin{abstract}
ABSTRAK
Kekurangan Energi Kronik (KEK) adalah salah satu keadaan malnutrisi. Dimana keadaan ibu menderita kekurangan makanan yang berlangsung menahun (Kronis) yang mengakibatkan timbulnya gangguan kesehatan pada ibu secara relative atau absolut satu atau lebih zat gizi. Kekurangan Energi Kronis (KEK) pada ibu hamil menjadi penyebab utama terjadinya pendarahan dan infeksi yang merupakan faktor kematian utama ibu. Permasalahan KEK ini telah dialami oleh negara-negara berkembang salah satunya Indonesia. Di Indonesia tahun 2016, terdapat sebanyak 79,3 \% ibu hamil berisiko kurang gizi. Sedangkan di provinsi Lampung pada tahun 2014, angka kecukupan energi dalam kategori kurang sebanyak 58,3\%. Kurang gizi pada ibu hamil dapat mempengaruhi proses pertumbuhan janin dan dapat menimbulkan keguguran, abortus, bayi lahir mati, kematian neonatal, cacat bawaan, asfiksia intra partum, lahir dengan berat badan rendah (BBLR).
\end{abstract}

Kata kunci: Kekurangan Energi Kronik (KEK), Gizi, ibu hamil

\section{ABSTRACT}

Chronic Energy Deficiency (KEK) is a condition of malnutrition. Where is the condition of the mother suffering from chronic food shortages (Chronic) which results in the emergence of health problems in the mother relatively or absolutely one or more nutrients. Chronic Energy Deficiency (KEK) in pregnant women is the main cause of bleeding and infection which are the main factors of maternal mortality. Developing countries have experienced this KEK problem, one of which is Indonesia. In Indonesia in 2016, there were $79.3 \%$ of pregnant women at risk of malnutrition. Meanwhile, in Lampung province in 2014, the energy sufficiency rate in the low category was 58.3\%. Malnutrition in pregnant women can affect the process of fetal growth and can lead to miscarriage, abortion, stillbirth, neonatal death, congenital defects, intrapartum asphyxia, low birth weight (LBW).

Key words: Chronic Energy Deficiency (KEK), Nutrition, pregnant mother.

\section{PENDAHULUAN}

Salah satu masalah gizi yang dihadapi di Indonesia adalah masalah gizi kehamilan. Kekurangan energi kronis (KEK) merupakan salah satu masalah gizi yang terjadi pada ibu hamil. KEK adalah keadaan kekurangan asupan energi dan protein pada wanita usia subur (WUS) yang berlangsung secara terus menerus dan mengakibatkan gangguan kesehatan. Permasalahan KEK ini telah dialami oleh negaranegara berkembang seperti Bangladesh, India, 
Indonesia, Myanmar, Nepal, Srilanka, dan Thailand. Berdasarkan profil kesehatan Indonesia tahun 2016, terdapat sebanyak 79,3 \% ibu hamil berisiko kurang gizi. Masyarakat dengan pengetahuan yang kurang tentang gizi biasanya terkena masalah gizi kurang ini Prevalensi ibu hamil yang mengalami KEK pada tahun 2013 di Indonesia sebesar 24,2\% dan mengalami peningkatan dibandingkan prevalensi risiko KEK tahun 2007 sebesar 21,6\%, sementara di Daerah Istimewa Yogyakarta (DIY) berdasarkan data Profi I Kesehatan Provinsi DIY tahun 2011 yaitu 14,8\% meningkat dibandingkan tahun 2010 sebesar $14,41 \%$.

Penyebab terbesar kematian ibu selama tahun 2010 sampai 2013 adalah pendarahan, hipertensi, infeksi, partus lama, dan abortus (Kemenkes RI, 2014b). Pendarahan menempati persentase tertinggi penyebab kematian ibu (28\%), anemia dan Kekurangan Energi Kronis (KEK) pada ibu hamil menjadi penyebab utama terjadinya pendarahan dan infeksi yang merupakan faktor kematian utama ibu (Apriyanti, 2017).

Salah satu faktor penyebab KEK adalah konsumsi makan yang tidak cukup mengandung energi dan protein. Kehamilan menyebabkan meningkatnya metabolisme energi, sehingga kebutuhan energi dan zat gizi lainnya meningkat. Selama kehamilan, diperlukan tambahan energi ekstra sebesar 340-450 Kalori setiap hari pada trimester II dan III. Kekurangan asupan energi selama kehamilan juga akan mempengaruhi kebutuhan protein. Jika ibu kekurangan zat energi maka fungsi protein untuk membentuk glukosa akan didahulukan. Pemecahan protein tubuh ini pada akhirnya akan menyebabkan melemahnya otot-otot dan jika hal ini terjadi secara terus menerus, akan terjadi deplesi masa otot karena salah satu fungsi dari protein adalah untuk pertumbuhan dan pemeliharaan sel-sel.

Salah satu dampak yang dapat dialami ibu hamil jika asupan zat gizi kurang yaitu akan mengalami KEK yang dilihat berdasarkan pengukuran lingkar lengan atas (LILA). Pengukuran LILA merupakan salah satu pengukuran antropometri untuk mengetahui ibu hamil tersebut menderita KEK atau tidak. Salah satu bentuk faktor risiko pada ibu hamil adalah Kurang Energi Kronis (KEK) dengan lingkar lengan atas kurang dari $23,5 \mathrm{~cm}$, atau penambahan berat badan $<9 \mathrm{~kg}$ selama masa kehamilan menandakan telah terjadi penurunan massa otot akibat kurangnya protein di dalam tubuh dan menandakan bahwa telah terjadi kekurangan energi secara kronis.

Faktor-faktor lain yang berhubungan dengan KEK pada ibu hamil yaitu tidak tersedianya pangan secara musiman atau secara kronis di tingkat rumah tangga . Ketersediaan pangan sangat bergantung dari daya beli keluarga. Jika daya beli keluarga menurun, maka ketersedian pangan juga akan menurun, begitu juga sebaliknya. Jika ketersediaan pangan di rumah tangga menurun, maka konsumsi makan dan asupan zat gizi per anggota keluarga berkurang sehingga menyebabkan masalah gizi. Berdasarkan hasil penelitian studi diet total (SDT) di provinsi Lampung pada tahun 2014, angka kecukupan energi dalam kategori kurang sebanyak 58,3\% dan yang baik sebanyak $31,2 \%$. Untuk asupan protein dalam kategori kurang sebanyak $45,9 \%$ dan yang baik sebanyak 18,6\%. Rerata asupan lemak sebanyak 45,1\% dan rerata asupan karbohidrat 196,5 gram sedangkan normalnya rerata asupan karbohidrat sebanyak 309 gram. Pada penelitian tersebut Lampung 
masih berada di lima besar kekurangan energi, protein, lemak, dan karbohidrat terbesar di Indonesia.

\section{MASALAH}

Alasan kelompok kami memilih kegiatan di Kampung Madiun Kelurahan Rajabasa Raya Kecamatan Rajabasa Bandar Lampung adalah karena dari kegiatan Survey Mawas Diri (SMD) yang diakukan didapati beberapa ibu hamil yang kami temui, adalah ibu hamil dengan kondisi kekurangan energy kronis (KEK)

\section{METODE}

a. Tahap persiapan

Tahap persiapan dari kegiatan ini adalah persiapan penyuluhan dengan media poster tentang ibu hamil KEK

b. Tahap Pelaksanaan

Kegiatan inovasi ini dilakukan pada tanggal 01 April 2021 pukul 14.00 WIB s/d selesai di BPM Hj.Martini,Amd.Keb.

c. Acara ini dilakukan dengan pemberitahuan berupa undangan kepada Bidan, Kader, Ketua RT dan Lurah Rajabasa Raya untuk meminta izin dalam rangka mengadakan kegiatan inovasi penyuluhan tentang ibu hamil KEK

\section{HASIL DAN PEMBAHASAN}

Metode pelaksanaan dalam kegiatan ini adalah penyuluhan kepada ibu hamil sebanyak 20 orang tentang kekurangan energy kronik dengan memberikan inovasi BULAT BRONIS.

Inovasi BULAT BRONIS ini adalah inovasi untuk Ibu hamil sehat bebas kekurangan energy kronik dengan cara memberitahu ibu tentang KEK pada ibu hamil dan pemberian makanan tambahan untuk ibu hamil KEK.penyuluhan di ikuti dengan antusias dan ibu hamil banyak yang bertanya tentang KEK, Penyuluhan berlangsung selama 40 menit dan terdapat peningkatan sebanyak $85 \%$ di lihat dari hasil postest.

1. Kekurangan Energi Kronik (KEK)

a. Pengertian Kekurangan Energi Kronik (KEK)

Kekurangan Energi Kronik (KEK) adalah salah satu keadaan malnutrisi. Dimana keadaan ibu menderita kekurangan makanan yang berlangsung menahun (Kronis) yang mengakibatkan timbulnya gangguan kesehatan pada ibu secara relative atau absolut satu atau lebih zat gizi (Helena, 2013).

b. Tanda Gejala KEK

1) Tanda-tanda KEK menurut Sediaoetomo (2012), meliputi:

- Lingkar lengan atas (LILA) kurang dari $23,5 \mathrm{~cm}$.

- Badan Kurus (BB tidak sesuai dengan tinggi badan)

- Turgor kulit kering

- Conjungtiva pucat

- Tensi kurang dari $100 \mathrm{mmHg}$

- Hb kurang dari normal (<11gr\%) 
2) Gejala KEK menurut Winkjosastro (2012), meliputi:

- Nafsu makan kurang

- Mual

- Badan lemas

- Mata berkunang-kunang

c. Penyebab KEK

- Ketidakseimbangan antara asupan untuk pemenuhan kebutuhan dan pengeluran energi.

- Usia ibu hamil, Melahirkan pada usia muda atau terlalu tua mengakibatkan kualitas janin/anak yang rendah dan juga merugikan kesehatan ibu. Karena terjadi kompetisi makanan antara janin dan ibunya yang masih dalam masa pertumbuhan.

- Jarak Kehamilan kurang dari 2 tahun mengakibatkan kualitas janin atau anak yang rendah dan juga merugikan kesehatan ibu. Ibu tidak memiliki kesempatan untuk memperbaiki diri, dengan mengandung kembali makan akan menimbulkan masalah gizi ibu dan janin berikut yang dikandung.

- Perilaku yang terdiri dari kebiasaan ibu: merokok dan mengkonsumsi kafein yang menghambat penyerapan zat-zat gizi yang dibutuhkan oleh tubuh ibu dan janin

d. Dampak Negatif Yang Ditimbulkan KEK

1) Pada ibu

Gizi kurang pada ibu hamil dapat menyebabkan resiko dan komplikasi pada ibu antara lain: Anemia, perdarahan, berat badan ibu tidak bertambah secara normal dan terkena penyakit infeksi. Sehingga akan meningkatkan kematian ibu.

2) Persalinan

Pengaruh gizi kurang terhadap proses persalinan dapat mengakibatkan persalinan sulit dan lama, persalinan prematur atau sebelum waktunya, perdarahan post partum, serta persalinan dengan tindakan operasi cesar cenderung meningkat

3) Janin

Kurang gizi pada ibu hamil dapat mempengaruhi proses pertumbuhan janin dan dapat menimbulkan keguguran, abortus, bayi lahir mati, kematian neonatal, cacat bawaan, asfiksia intra partum, lahir dengan berat badan rendah (BBLR) (Helena, 2013)

e. Cara Mencegah KEK

1. Syukuri dan nikmati anekaragam makanan

2. Banyak makan sayuran dan cukup buah-buahan

3. Biasakan mengonsumsi lauk pauk yang mengandung protein tinggi

4. Biasakan mengonsumsi anekaragam makanan pokok

5. Batasi konsumsi pangan manis, asin dan berlemak

6. Biasakan Sarapan

7. Biasakan minum air putih yang cukup dan aman

8. Biasakan membaca label pada kemasan pangan

9. Cuci tangan pakai sabun dengan air bersih mengalir

10. Lakukan aktivitas fisik yang cukup dan pertahankan berat badan normal. 
JPM (Jurnal Perak Malahayati), Vol 3, No. 2. November 2021,

E:ISSN 2684-8899 (Online) P:ISSN 2685-547X (Cetak), Hal 113-119

\section{DOKUMENTASI}

\section{KEGIATAN PENYULUHAN INOVASI BULAT BRONIS}

(Tgl 01 April 2021)
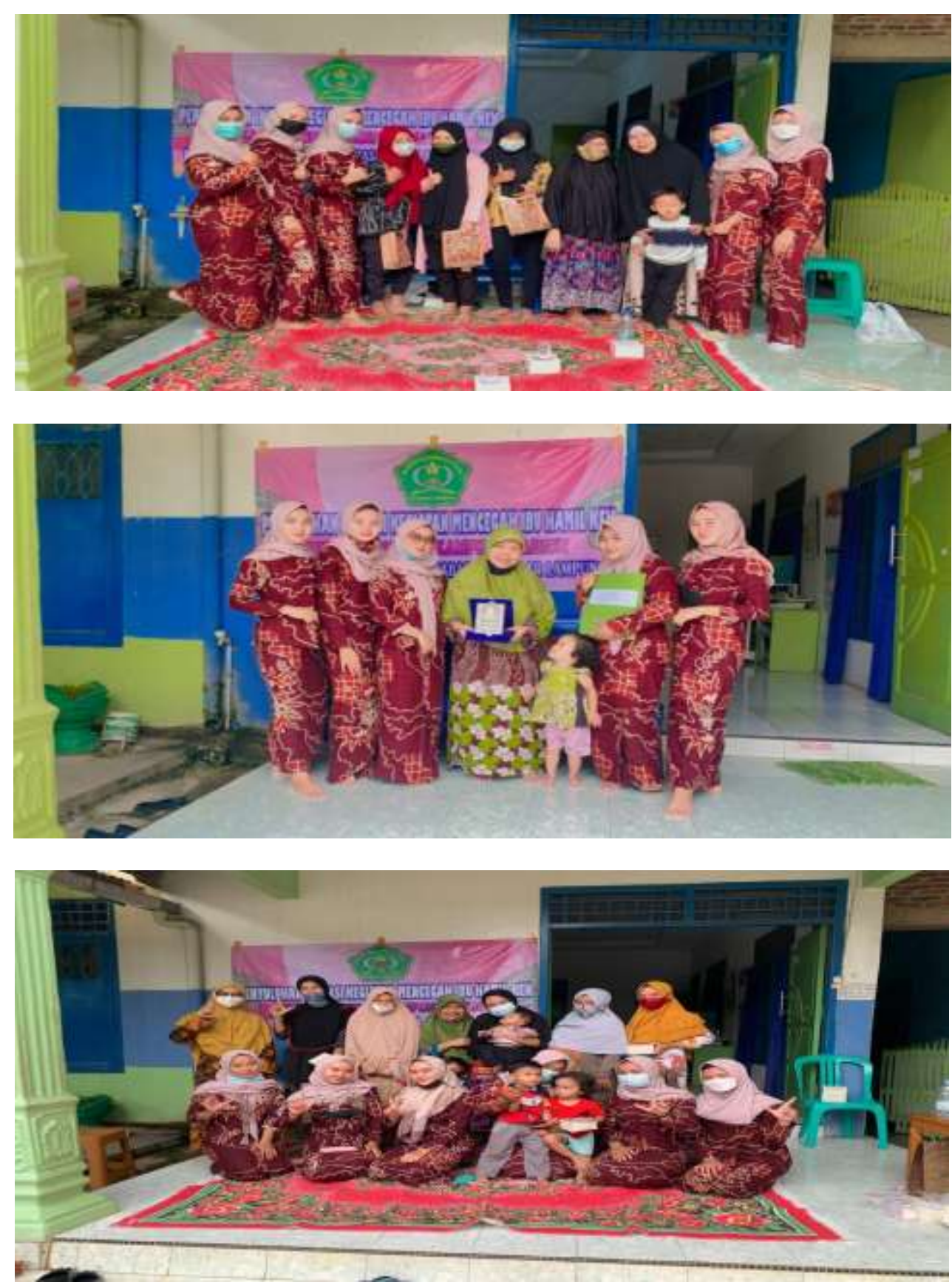
Devi Kurniasari, Rosmiyati
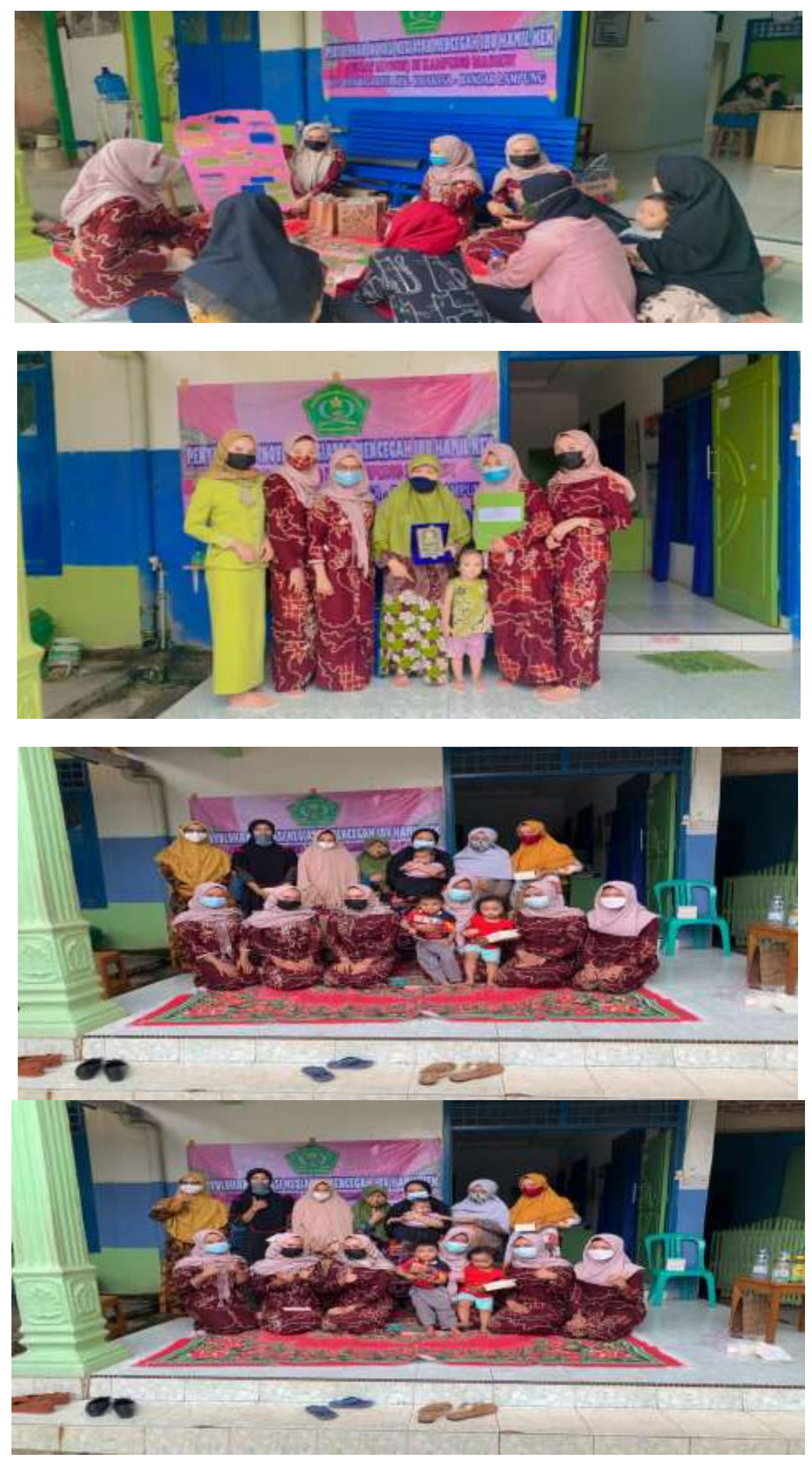


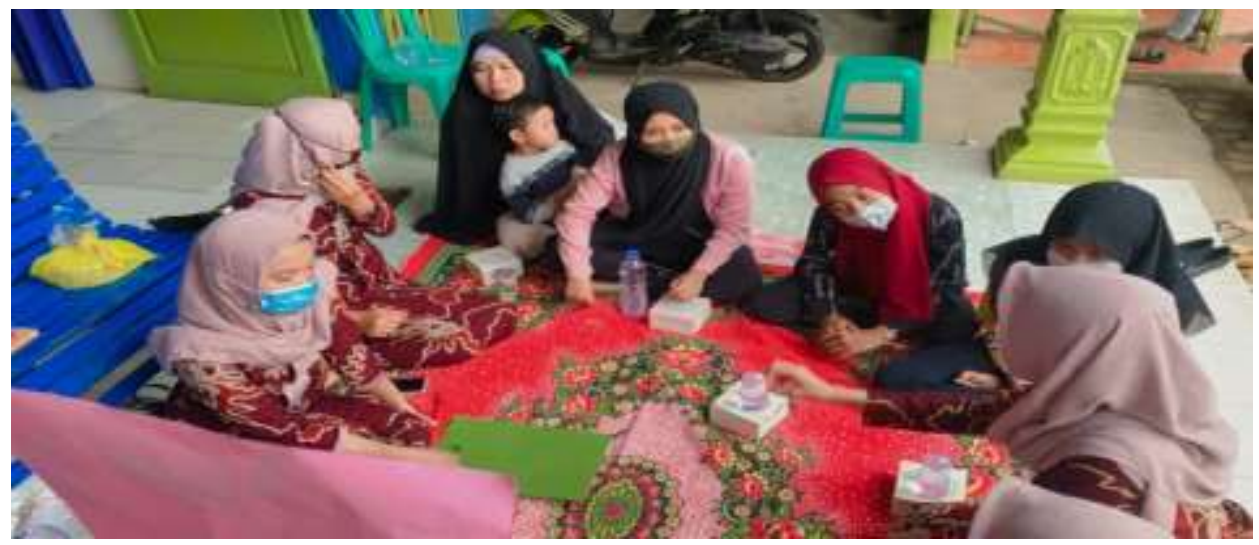

\section{DAFTAR PUSTAKA}

Mariza, A., Sunarsih, S., Yuliasari, D., \& Anggraini, A. (2021). Penyuluhan Penggunaan Jahe Merah Sebagai Terapi Non Farmakologi Untuk Mengatasi Nyeri Haid Pada Remaja Putri Di SMA Muhammadiyah 2 Bandar Lampung. JURNAL KREATIVITAS PENGABDIAN KEPADA MASYARAKAT (PKM), 4(3), 656-661.Nabila, Sarah. 2018.

Kurniasari, D., Putri, R. D., \& Hermawan, D. (2019). PENYULUHAN TUMBUH KEMBANG BALITA DI DESA JATIMULYO KABUPATEN LAMPUNG SELATAN. JURNAL PERAK MALAHAYATI, 1(1).

Satuan Acara Penyuluhan (SAP) Kekurangan Energi Kronis, sarrnabila.blogspot.com. diakses pada tanggal 19 maret 2021 pukul 13.30 WIB.

Pratama, myogha. 2019. SAP Penyuluhan BGM, id.scribd.com. diakses pada tanggal 19 maret 2021 pukul 13.00 WIB.

Utami, V. W., \& Yuliasari, D. (2020). SOSIALISASI PROSES PERSALINAN YANG AMAN DI ERA PANDEMI COVID-19. Jurnal Perak Malahayati, 2(2), 105108. 